\title{
Prefabricating Stories: Innovation in Systems Technology after the Second World War
}

\begin{abstract}
NICK HAYES
Commenting in 1944 on the future design of housing for post-war reconstruction, the British government's Central Housing Advisory Committee, an eclectic body of expert talents, noted that:

The process of housing construction is developing in the direction of the greater preassembly of parts of the house at the factory. It is not yet possible to state with any confidence how far such methods can be carried with satisfactory results. While, therefore, the case for entire prefabrication is by no means established, it is possible that in the future complete houses may come to be built in this way. ${ }^{1}$
\end{abstract}

How should we read such a statement? Stories about buildings, and thus their social meaning, vary considerably through time. ${ }^{2}$ Without knowledge of the 'high-rise' systems debacles of later decades, we might wonder at CHAC's cautious optimism. Yet we might ponder, too, that during the inter-war years site methods had shifted only 'very slowly from making to assembling, ${ }^{3}$ Learning that earlier experiments with prefabricated houses had failed technically, were more expensive than traditional methods, and were remembered unfavourably by enthusiasts and consumers alike, acting as contemporaries we might then dismiss such forecasts as fanciful and self-deluded. ${ }^{4}$ Indeed, on being harangued by Picture Post (the exemplar advocate of reconstruction) one month later that 'we must work out some totally new way of building' — demand the 'prefabricated house' - we might rightly conclude that we had entered a looking-glass world. ${ }^{5}$

Technology is a social product: understanding the social dimension, it is argued, is crucial to our understanding of its success or failure. ${ }^{6}$ Housing, especially, has a close and intimate social meaning. Of course, most of us have specific, personalised understanding(s) of everyday things: our homes included. What we understand, individually or as groups, we understand through different filters, for different reasons, and with different priorities. Thus, while technologists spent the war years enthusiastically investigating building systems utilising steel and concrete that used less skilled site labour to construct the external shells of houses, for tenants physical structure remained only immediately significant if it 'was defective and let the rain through'. Contextually, anyway, most householders were 'incapable of imagining the sort of world where they would be allowed to choose the home they wanted'. External appearance for housing authorities, however, was important; new housing stock ideally had to marry with existing. ${ }^{7}$ And planners, architects and politicians - experts generally - it is argued, also had different group visions: lest we too readily conflate the widespread popular interest in housing at a time of acute shortages with shared professional preoccupations. $^{8}$

Yet the limits and range of shared social meanings are important to understanding technological development. ${ }^{9}$ Meaning through interaction brings agency, direction, cohesion. It sets markets, creates networks and stamps trajectories. But how is meaning 
attributed? First, there is a story of internal coherence, the basis on which we judge buildings or other products in themselves, how we comprehend their purpose aesthetic, function, economy, etc.. The second is the story of their external explanation, of causes and context - 'broader meaning'. ${ }^{10}$ Both components have strong human agency: of commitment, rationality, necessity, expense, scarcity, etc.. This article explores the interactive nature of 'shared meaning' across this divide between social groups, and the impact this had on the development of low rise systems housing after 1945. It will suggest that this 'new' technology was widely and continually misunderstood and interpreted by different groups in very different ways, limiting agreement, product stabilisation and closure. ${ }^{11}$ This proved inimical to subsequent development.

\section{ACTORS AND CONVERSATIONS}

Writing in the mid-sixties, Marian Bowley noted that 'innovations in structures and methods of design' had 'developed very tardily in this country': evidenced by 'woefully little general interest in research', in 'economic rationality in design', or in offering customers choice. ${ }^{12}$ Particularly important here had been the separation of the design and construction functions, so neither architect nor builder had the incentive or authority to conjure innovation. Even greater explanatory weight has subsequently been assigned to this 'social' dimension of organisational interaction. ${ }^{13}$ If 'successful innovation requires the coupling of the technical and economic, rather than being solely a matter of "technology push" or "market pull", then inter-functional co-operation and communication offers the very force for change. ${ }^{14}$ This is perhaps even truer of construction, as essentially an assembler of other manufacturers' products: 'really just a network and a set of lists, like a telephone directory', perhaps with 'too many characters and no plot'. In this anarchic system, 'common meaning' and 'common understanding' were therefore at a premium; ${ }^{15}$ the 'quality' of conversation (that is, information and knowledge) between actors having a significant impact on the force and direction of innovation. ${ }^{16}$

Yet supplier-dominated concerns like construction, it is argued, 'appropriate less on the basis of technological advantage, than of professional skills, aesthetic design,' etc.: ${ }^{17}$ where design is seen as more an art than as a science. If this was true of traditional 'bricks and mortar' construction, a sector exemplifying small, low-visibility, and cumulative change, was it also true of non-traditional, systems forms of construction? ${ }^{18}$ Contemporaries argued not. As one prominent building economist noted at the end of the war, there was 'some reason for believing that at last ... a genuine revolution in technique' was about 'to take place.' Scientific discourse, too, was 'swinging against ... traditional methods' towards non-traditional methodologies. ${ }^{19}$ Such beliefs were certainly advanced by architectural theorists on other than aesthetic grounds (for example, in terms promoting 'modernising' industrial efficiency). These discourses coexisted with increased technological investigation into new building methodologies. Each gave the other validity and vitality, even if the claims made were questionable.

Beyond this, did non-traditional networks conform to the same 'conversational' patterns between actors as in the industry generally? In public housing contracts the customer was 'not an individual' but a 'complex system of differing interests'. 'These client systems ... consisted of both congruent and competing sets of understandings, 
values and objectives' ${ }^{20}$ Architects provided a powerful professional social filter: as intellectual initiators, and thus as interpreters of the client's fluid demands. Historically they also led the building industry: from the architects' viewpoint, the construction process 'was hierarchical both socially and in terms of working organisation'. ${ }^{21}$

Yet local authorities frequently did not employ architects directly. Moreover, a clear majority of the low-rise housing systems introduced after 1945 was sponsored by building contractors or component suppliers. ${ }^{22}$ Did this mean that architects - as professional gatekeepers - were less influential in determining outcomes? A preliminary review would suggest not. Non-traditional housing was almost exclusively a public sector activity, where tenants' views (directly or indirectly) were not actively sought. 'Consultation' consisted of numerous educative exhibitions and a plethora of pamphlets and books to transmit an imposed experience. The 'community' anyway, apparently, was less interested in 'planning', etc., than more immediately in 'houses at any price'. ${ }^{23}$ Neither were local authorities, as purchasing agents, actively consulted. Instead, they were invited to inspect and consume, advised by ministry architects, but otherwise largely excluded from the early decision-making process. ${ }^{24}$ Thus, the 'design of social housing' was controlled 'by the makers of social policy. ${ }^{25}$ It was they who instituted a 'way of thinking' about future problems and what was possible, possessing and applying a 'set of knowledge' and 'expertise' that gave authority and direction. ${ }^{26}$ Attention, therefore, has centred on architects as the instigators of systems methodology, although others - such as politicians, government departments and national housebuilders - are also cited as co-correspondents. ${ }^{27}$

From this, the historiography focuses on the role of ideas and myth; the binding together of mutual interests utilising a 'misleading' hegemonic discourse. ${ }^{28}$ Here rationality is subverted and prefabrication is chosen over traditional forms of construction despite being more expensive, flawed and less popular with tenants. Actor innovators, anyway, do not always treat consumer preferences as 'unalterable structural constraints' on their own behaviour. Technological trajectories can accord more with speculative 'early promises' than hard information. ${ }^{29}$ In this respect, of primary importance in determining trajectories are the a priori beliefs held by actors - their problem solving rules, specific knowledge, etc, and the social/environmental hierarchy that determines which beliefs are privileged at a particular time. ${ }^{30}$ In 1940s Britain politicians and housing experts, it is argued, came to believe that a 'technical breakthrough' in housing was necessary and had actually occurred, allowing them political and economic freedoms in terms of production that otherwise would have been closed because of acute factor shortages. ${ }^{31}$ Rationality and irrationality, it can thus be argued, existed in many forms when socially or politically contextualised. The pricing mechanism, by itself, although important, offered only one check for decision-makers. Others at the time included gross national labour saving potential, or the need to maximise housing output (from either a governmental or commercial standpoint). Thus, what was rational from one viewpoint, was irrational from another. ${ }^{32}$

If, therefore, common understanding between producer and consumer was only partially present (in that needs, expectation and promises overlapped), between producers (that is designers and builders) and policy-makers (politicians and state servants) a greater congruence existed. But was this sufficient? In the first decade after the war, the state licensed all new building work. Thus it had a controlling hand. In 
addition little 'hard evidence' existed either against which to test the claims being made for non-traditional techniques, although early scientific evaluation did validate initial belief systems. Yet there was an element, too, of wishful thinking in such assessments. ${ }^{33}$ Indeed any reliance on myth suggests that ambiguity existed amongst and between actor clusters. Pinch and Bijker argue that the technical stabilisation of a product - that is the closure of controversy - occurs not when all problems are solved, but when 'relevant social groups see the problem as being solved." 34 The remainder of this article will explore whether this occurred.

\section{PREFABRICATION: MORE IN THE MIND?}

Interviewed in 1944 on his return from a fact-finding tour of the USA, Sir George Burt stated that 'if the Enquiry dealt with one point, it established that so far as prefabrication is concerned it exists in America more in the imagination than in practice'. Asked then whether the setting up of factories to produce prefabricated shells and structures in Britain would not assume continuous demand for years, he advised that:

I think that this is one of the principal stumbling blocks so far as this country is concerned. I have seen no prefabricated house which will be so popular as to create a home market which will justify the somewhat elaborate equipment necessary. In the immediate post-war period it may be necessary to use a prefabricated outside structure to save site man-hours.... [but] I can see no permanent future for such structures. ${ }^{35}$

Burt was not only a prominent national contractor; he also chaired the government committee then investigating alternative methods of house construction. But his comments are contextually significant for other reasons. 'Modern' England, as Priestley recognised in 1934, was already heavily overlaid by American influences. ${ }^{36}$ And, in terms of prefabrication, historians have stressed the impact that the idea of America had in shaping the British psyche. ${ }^{37}$ It is easy to see why, when Picture Post, for example, argued that 'Prefabrication had Cut Down America's Housing Problem'. Prefabricated houses were erected 'in a Day'. 'Your whole house may be erected in a factory and trucked to site, as has been done in America ... Millions of us will have houses like this'. ${ }^{38}$ Nor was the architectural press exempt from this hyperbole. Architectural Review, an early advocate of modern design, argued that success in America 'hands us a sharp jolt on the chin.' Focusing on 'prefabrication', and 'the complete factory assembly', it went on to claim that 'The phenomenal U.S. housing output is to be interpreted as an omen of the future... It shows that it is possible to produce houses quickly, with a high standard of performance and with excellent equipment. ${ }^{\text {, }}$

Yet there was nothing extraordinary about these discourses. Even stripped of its transatlantic focus, to the wider British audience such 'adverts' spoke of what might be obtainable through British technical ingenuity if only ... (just as British technical knowhow had triumphed during the war). ${ }^{40}$ Indeed perhaps the semi-illusory quality made the offer more attractive and magical. However, a fascination with what was 'possible' - a mutually accepted interpretation of what technology might provide - needs to be grounded against the public's 'deep anxiety' about housing shortages, which formed the political backdrop. ${ }^{41}$ Commenting on public reaction to an exhibition on post-war homes 
designs, Mass Observation, the influential pioneering social research organisation, recorded that:

People just wondered when all these things would be available, whether they would really be available at all. As one young middle-class woman, married and homeless, said, "They could just give me any of it, and I should think it wonderful. Honestly, I liked it all. I'm so desperate for a home I'd like anything. I can't criticise or judge it at all - four walls and a roof is the height of my ambition."

The 'very nice if we ever get it', 'very good, but the point is, how long will it take before they carry it out' mentality was evident elsewhere. ${ }^{43}$ Architectural commentators, judged by the plethora of validatory articles on prefabrication then appearing in the technical press, were significantly ahead of the profession or political opinion. ${ }^{44}$ The Royal Institute of British Architects had apparently been 'ostrich-like' in its pronouncements; even in the last months of the war it was still writing reports 'from a position deep in the rear'. The press noted, too, that 'prefabrication had been too much on the defensive'. Mistakenly, prefabricated houses were still not 'put forward as a better method of building than brick and mortar, but simply as a method of building houses without employing bricklayers and plasterers.' 45 'We hardly yet know how to use it', opined the Architects' Journal at the end of 1945: 'Laboriously we imitate the old brick house in form and content. Our prefabricated efforts are mere copyism, their explosive potential still unrevealed. ${ }^{46}$

A consensus was lacking, therefore, over what should be valued or produced. Early reports from the secretariat of the Burt Committee noted that:

no proposed method satisfactorily solves the problem of producing houses cheaply. The methods suggested are complicated. I think this is due to the fact that the simpler methods of improvement on the basis of existing practice have been exhausted, and that attempts are being directed to entirely new methods, not yet properly directed. ${ }^{47}$

Others were harsher. The Ministry of Works Deputy Chief Scientific Advisor, commented of existing inter-war systems that:

Many alternatives were tried, and in one respect or another were found wanting. Some of the houses then produced turned out to be thoroughly bad; others proved more costly than the traditional houses, and as a result the alternative systems in use [by 1939] could be numbered on one hand and none was working on any large scale. If we consider the state of scientific knowledge in 1920, it is not a matter of surprise that the alternatives used were unsuccessful. There was no basic scientific data concerning the properties of and behaviour of building materials except for a limited and very narrow fund of knowledge of their strength. ${ }^{48}$

It is not surprising, therefore, that the Burt Committee's initial temper was very cautious, evaluating and reporting on inter-war practice rather than looking to current and future research. ${ }^{49}$ Yet, as the Architects' Journal commented, what purpose did this serve? A 'far more valuable contribution at this point would be a report, less unadventurous than 
this first, on entirely new experiments - especially those concerned with prefabrication'. 50

If architects and builders remained uncertain of what or how to build, the community seemed equally bemused by non-traditional design. One engineer, for example, reporting on 'overheard conversations ... at recent and numerous Housing Exhibitions', recalled that 'misunderstanding and prejudice are about equally mixed in the public mind'. This was the product of 'cellophane wrapped publicity campaigns' and the 'deeply rooted ... acceptance of brick-wall and pitched roof traditional construction ... as the ultimate in building technique'. ${ }^{51}$ Certainly, public responses tended to reinforce this view. For example, numbers of people were 'definitely put off' certain non-traditional types (for, example the Orlit and Unibuild) 'simply because the roof was flat.' Yet the Orlit was also the most popular of house types then being displayed by the Ministry of Health. At least it looked 'permanent', 'attractive', 'spacious'. Steel and asbestos-cement clad houses, by contrast, (the British Steel and Braithwaite) were viewed negatively, as being 'cheerless', 'cold' and 'barracky' - 'imagine rows and rows of them'. Indeed, on all non-traditional types, 'by far and away the most unpopular comment was on the external appearance of the houses'. Within a 'comparatively low level of positive interest' generally, a 'quite like them if I could get nothing else, but they've no individuality' view dominated in the public mind. ${ }^{52}$

\section{Insert photos Orlit (Figure 1) and Braithwaite (Figure 2)}

Non-traditional houses thus continued to be viewed, as they had in the inter-war period, as 'makeshift' or 'temporary', where local authorities saw them as 'ten year' expedients after which the government would 'take the damned things away'. ${ }^{5}$ Indeed misunderstanding, apparently, was endemic: 'much nonsense' being 'talked about prefabrication, chiefly because the meaning of the word has not always been fully understood'. 54 Did it mean, as was commonly implied, 'the manufacture of the complete house and its rapid and mechanical erection on site', or rather, as the Burt Committee and many architectural opinion-formers would rather have it, 'the application of certain factory methods in the mass production of certain component parts, thereby reducing site costs' for everyone? ${ }^{55}$ Apologists for traditional methods again blamed the 'confusion of thought' on the 'political propagandists' of prefabrication:

They insist on representing it as a technique providing a ready-made solution to the housing problem, gifted by progressive scientific thinkers to a grateful nation, but rejected by a backward and reactionary building industry, intent on preserving intact the twin citadels of craft monopoly and swollen profit. The public has been led to suspect that houses might now be rolling off the production line like typewriters or motor cars, were it not for the hidden and frustrating hand of vested interest. ${ }^{56}$

Contextually it is easy to see why 'traditionalists' felt themselves to be under siege, and prefabrication discourse thus privileged. The war years had heavily distorted the building industry. Labour productivity fell markedly, and remained stubbornly below pre-war levels after 1945. As demand for housing soared, one consequence was that the industry was viewed by politicians, economists and by scientific advisors alike as 
'backward' and in crisis: ${ }^{57}$ technically deficient, conservative in its use of mechanical plant, poorly trained, ignorant of recent research and resistant to the use of 'new methods'. 58 Bevan, as the minister responsible for housing, thought it 'vital' to provide an external 'stimulus to the building industry from outside ... by introducing new techniques'. Both he and Morrison, then in charge of co-ordinating domestic policy, understood permanent prefabrication in terms of a 'modern' alternative providing 'competition for construction. ${ }^{59}$ Cautiously stressing what had 'been tested and found by experience to be good' acquired an instinctive dissonance against this rhetoric. ${ }^{60}$

During the war the only development licences issued were for prefabricated or other experimental methods of building. Effectively this became the only game in town. Thus, the architect Richard Sheppard, surveying wartime developments, could justifiably comment in glowing terms on the much publicised proliferation of new prefabricated designs. ${ }^{61}$ Sheppard favoured collaborative design, bringing together architect, production engineer, planner and structural engineer, replete with an ongoing scientific investigation into building materials and performance. ${ }^{62}$ Indeed, the aggressive cultural promotion of new methods by certain architects and builders, the technocratic faith in experts, and the advance of scientific investigation, walked hand in hand. ${ }^{63}$ The 'normal method of evolution of new forms of building' was a 'trial and error' process, taking considerable time. But time, it was argued, was now simply not available. ${ }^{64}$ Science and technology offered an alternative path.

Yet the limits that the architectural modern movement and scientific influence had in redefining the house can be measured by looking briefly at what was actually constructed. The majority of systems houses built after 1945 were concrete based (either cast in situ or prefabricated); second in popularity were those with a steel frame. Two builders (Wimpey and Laing) between them constructed a third of the 271,000 nontraditionals built in England and Wales in the ten years after the war: and both house types were cast in situ. ${ }^{65}$ There was nothing new about such systems. Some 2,000 Laing's 'Easiform' houses had been constructed before 1939; and slightly fewer 'no fines' (although not by Wimpey). ${ }^{66}$ Both Laing and Wimpey were major speculative builders, initially producing non-traditionals because as 'normal building was expected to be limited by lack of traditional resources, it offered the prospect of a market. ${ }^{, 67}$ Neither house when assessed by the Burt Committee in 1944, was thought exceptional or worthy of praise. Instead they were judged 'a satisfactory alternative, if properly used, to brickwork', but 'not technically outstanding in such a way as to deserve special treatment.' Much greater interest, for example was shown in steel framed factorymanufactured structures. It was the latter that was preferenced developmentally, for it was considered that the 'steel frame might form the basis of a true shop-fabricated demountable house.' 68 This belief that the output of the building industry could 'only be increased by using new [factory] methods' was deeply ingrained within the political structure also, so that early setbacks were discounted. Indeed considerable disappointment was expressed that too many of the systems being introduced 'did not comply with the principles of prefabrication', and 'represented merely a method of construction'. ${ }^{69}$ All systems construction was justified by the operating premise of its greater efficient use of scarce site labour. But the power of the ideal - that is shopbased prefabrication - flagged a heavy discrepancy between what was desired and what was finally produced. 
Yet the broader idea of 'new methods' was certainly pinned, if not driven home, by the rapid expansion of systems construction. Although later falling, by 1948 nontraditional construction accounted for one third of all public sector completions, a figure not subsequently exceeded until the high-rise boom of the late $1960 \mathrm{~s} .{ }^{70}$ Indeed at one stage the Cabinet considered that some 75 per cent of permanent homes would be constructed by such 'labour saving methods.' 71 Nevertheless, even when successful, the governing philosophy of systems construction remained ambiguous - that is in terms of closure and stabilization through time. The point is again well illustrated by looking at cast in situ housing. The 'no-fines' and Easiform systems remained popular well into the 1960s and 1970s. In these years Wimpey alone was casting on average some 8,000 units per annum in England and Wales. 'No fines' options proved to be equally popular in Scotland. By and large such houses performed well: 'no fines' concrete walls were 'quickly built with very little skilled labour'. ${ }^{72}$ Thus it was well liked by local authorities. But this popularity also rested with the appearance of 'no fines' construction, because once rendered externally, it passed for a traditionally built brick house. As Mass Observation observed, 'the less a prefab. looks like a prefab. the more people like it'. Some local authorities "simply switched from brick to "no fines" in situ concrete and back again, according to the availability of materials and labour. For others it became the system of choice. ${ }^{73}$

INNOVATION, EVALUATION AND LOTS OF PREJUDICE

Bowley argues that 'most of the systems proposed, and still more those actually used, were fundamentally similar to those used in the inter-war period'. New methods were not new at all. For her, perhaps the 'greatest innovation' was 'less in the actual methods and materials used, than in the development of the scientific assessment of performance. ${ }^{, 74}$ This offered the first objective technical standards against which performance could be measured (for example, thermal and sound insulation, resistance to fire and moisture penetration, stability, etc.). But 'neutral' state sponsored science also became an evaluating weapon through which non-traditional methodologies could be and were promoted. Even before a detailed re-evaluation had commenced, science - in the form of the Building Research Station - spoke authoritatively about why earlier building systems had failed, and about its own current predictive powers to prevent such a physical reoccurrence. ${ }^{75}$ At the same time the BRS readily admitted to the paucity of information existing on costs and labour content for housing generally — ' a remarkable dearth' of real systematic data: a major shortfall given that 'cost or demand on human effort is one of the final criteria in deciding on the merit of a new or modified form of construction. ${ }^{76}$ Science was to fill such voids in 'traditional knowledge': that which had served the industry 'so well in the past', but was 'no longer sufficient to meet the needs of modern conditions' ${ }^{77}$

Thus, the BRS's publicly declared advice to architects was that, given the 'large fund of scientific knowledge of the physical, mechanical and chemical properties of building materials the problem of the design of new methods of construction presented no 
formidable obstacles. ${ }^{, 78}$ Such advice was disingenuous. Privately the BRS was advising the Burt Committee, for example, that the performance of light steel framed houses was likely to be unpredictable after twenty-five years. It similarly refused to vouch for the efficiency of jointing systems utilised unless they could be tested in advance over time. Nevertheless it was argued that the development of such houses for 'immediate post-war use' should not be 'prejudiced by certainties as to the ultimate length of life arising from either the corrosive or the jointing issue. ${ }^{, 79}$ Nor were jointing problems unique to steel houses. Similar shortcomings were encountered with pre-cast concrete houses but were again controversially gilded over in favour of production immediately. ${ }^{80}$

In re-evaluating non-traditional performance in the early 1950s, ministry officials referred to an immediate negative 'legacy of the past'. Poor technical performance 'causing considerable trouble and expense in remedial measures' was one such failing, as were 'slow completion' rates, extra costs and the widely held belief that 'non-traditional houses were uglier that brick houses. ${ }^{81}$ In part this ignored the overall realities of the non-traditional versus traditional debate. Delays were endemic at that time across the board. Similarly, while non-traditional designs might 'accentuate' some of the difficulties of poor estate layout, and were certainly thought of as 'all looking alike', this was not a problem intrinsic or unique to them, but common on traditionally constructed estates too: 'where all individuality and homeliness have been lost in endless rows of identical semi-detached houses. ${ }^{, 82}$ Nevertheless, such an overview offered an accurate measure of perception: as one Regional Housing Officer remarked there was an 'array of snipers abroad', all 'quick to seize upon and criticize any fault' in the non-traditional housing types. ${ }^{83}$ As Bevan acknowledged, he expected positive steps to be taken to 'encourage' public authorities to place orders for non-traditional housing and 'to do everything possible to overcome the prejudice that still exists in all quarters against new building methods. ${ }^{84}$ That this was necessary reveals the large gap that existed between 'promoting' government agencies and local authority consumers; one that remained after teething problems with earlier, more unreliable systems had been overcome.

It is useful also to contrast Bowley's postoperative view of the lack of technical innovation with that of contemporary advisors. Addressing building employers at the end of 1949, the Director of Research at the Ministry of Works began by noting that 'it had not been possible in the last thirty years for the building industry to provide a house at a rental within the means of the workers in the lower income groups.' Low-cost housing, he correctly summarised, "has had to be subsidised. ${ }^{85}$ He then outlined the recent advances made, continually contrasting these against a slow moving building industry 'firmly entrenched in traditional practice, ... founded upon craftsmanship' and making materials fit on site. 'The new methods of production differ from the old', he stated, in that 'by definition, every stage is planned and the whole process is in every case rigorously controlled by the requirements of production'.

The actuating theory has been that structural components should be made to accurate dimensions in factories and they should then be assembled on site with a minimum of labour. In fact, the expected economies in labour have been achieved handsomely. The components have been made accurately and they have been assembled quickly and easily. ${ }^{86}$ 
Indeed, he concluded, 'the pity of it all' was that such techniques had so far been limited only to the shell of the house, as he announced plans to fabricate completely the interiors and finishings in the factory also.

There is no record of audience reaction to such claims, although it is unlikely to have been sympathetic because most contractors continued to favour traditional methods. ${ }^{87}$ It would have been less sympathetic still had the audience fully appreciated how radically estimates of man-hour savings then being presented to them had fallen from the initial figures that had first underpinned prefabrication policy. As Bernal, then chairing the MOW Scientific Advisory Group, pointed out in early 1946: 'It appears that much of the time-saving in certain types of prefabrication is more apparent than real. ${ }^{, 88}$ Again it was 'outstanding' houses like the Reema and Wates that were praised by the BRS: those predominately prefabricated off-site and thus most readily conforming to the ideal of factory methodology. The government's report on non-traditional performance reminded its audience that success 'depended on the basic principle of exploiting the machine to the full, assembling very rapidly on the site a number of accurately dimensioned units which require no elaborate fitting together. ${ }^{89}$ New methods, however, were still no cheaper than traditional forms of construction, and indeed only 'no fines' offered immediate prime cost savings. ${ }^{90}$ Nevertheless the development of pre-cast concrete housing systems was to be dominated by a single theme: bigger panels incorporating an increasing number of functions (for example, a pre-finished internal skin). The Reema and Wates systems were early exemplars. As the BRS noted, it seemed reasonable 'to make the units as large as the mechanical equipment can conveniently handle. ${ }^{91}$ Here we see a glimpse of the future. Building high, the next stage, was always to be more expensive. This led to the lowering of specifications and design standards in the utilitarian blocks of the 1960s and 1970s. Practical limits existed also to the economic size of off-site prefabricated units, and high factory-based overhead costs married uneasily with fluctuating demand. Moreover the efficiency claims made for systems construction as likely reflected more efficient site management structures than the system methodology per se. ${ }^{92}$

Insert Wates (Figure 4) photo

Such ante-dated realities sit uneasily with science's predictive confidence in the 1940s. And perhaps post-knowledge criticism is unfair. Well, not really. The authority of such discourse was itself created initially by contrasting an earlier lack of knowledge with what was now 'understood' about material behaviour and areas such as works study. Contemporaries also already suspected that productivity gains attributed to nontraditionals were a product of better site organisation. Indeed the concluding remarks of the first Burt report of 1944 captured exactly this latter sentiment. ${ }^{93}$ When such questions were raised, however, the answer, although present in the analysis, was not one that was emphasised or headlined. It remained buried, neutrally, in the main body text. ${ }^{94}$ We can contrast this 'sleight of hand' against the emphasis taken by those major overarching enquiries into building efficiency at that time. These virtually discounted the probability of gains coming from shell prefabrication or indeed from prefabrication generally. ${ }^{95}$ Nevertheless, for politicians, science's role was axial; its course and agenda set. Writing to Morrison, the Minster of Works put this perfectly. All agreed on the 'importance of research work in the field of building and civil engineering from the point of view of the 
efficiency', and making 'the most economical use of man-power and material as well as from the point of view of cost.' The 'time has come when the underlying problem of modernising the building industry and putting pressure on it to become technically efficient will have to be faced.' 96 Indeed construction's very backwardness was publicly defined in terms of its reluctance, as an 'ancient industry, rooted in tradition and craft practice', to adopt mechanisation and prefabrication - the products of scientific investigation. $^{97}$ If we factor in the prostituted use of this broader scientific discourse through systems advertising and 'neutral' technical reviews (where such language underlined manufacturers/designers claims), the rhetoric of science had a significant impact in promoting systems mentalities. ${ }^{98}$ But it also exacerbated the gap between the 'new' and 'old', between traditional and non-traditional. Thus, only in one sense did it aid understanding, and then only partially.

Bowley, writing at the time of the later high-rise boom, acknowledges that, while most of the non-traditional low-rise systems used after 1945 were 'fundamentally similar' to those used between the wars, there were what she terms 'novelty' innovations. Included here was the use of the large pre-cast load-bearing panel (that is the Wates and Reema systems already noted), and of light-weight steel frame fabrication. Most of the innovative steel frames solutions, she notes, failed to be developed - partly because government policy towards steel houses changed significantly due to post-war steel shortages. Other 'genuine innovations' could be found in the use of aluminium and plywood for the construction of internal and external skins. ${ }^{99}$ Some historians have been more generous. Finnimore, for example, points out that the majority of non-traditional dwellings 'used materials new to housing such as concrete, steel and laminates', noting again particularly those 'systems which used the latest techniques in light weight steel fabrication.' He concludes that of 'more impact than the real extent of mechanised production was the innovative nature of the materials and methods of construction used. ${ }^{100}$ Such praise requires obvious qualification because steel and concrete were central components of earlier inter-war systems. Even those types noted as innovatory in their use of materials - like the BISF type of which over 31,000 were built - were modelled loosely on earlier inter-war types like the Dorlonco (itself then considered to be an 'important technical step forward'). ${ }^{101}$ For some house types, such as the steel prototype Braithwaite, it was the method of 'clip' jointing that was deemed to be important. ${ }^{102}$ Indeed a frequently stated reason for the post-war 'failure' — if such it was - of non-traditional housing was that it focussed on too many 'novelty' individual private designs, so markets for each were correspondingly limited, when what was really needed was a broader trajectory of prefabrication and standardisation. ${ }^{103}$

\section{Insert photo's of BISF (Figure 5) and Woolaway (Figure 6)}

There is some sense to this. Certainly the production of certain house types was driven forward by little but entrepreneurial enthusiasm, and this was really part of the infectious post-war hype associated with non-traditional methods. The Woolaway - a pre-cast system - was one such: poorly reviewed in terms of its physical and design attributes, and lacking the necessary finance. Even the Minister responsible recognised its limited potential: 'only one of a hundred' such approved systems, and 'not of any outstanding merit', but nevertheless encouraged as 'a useful supplement to traditional 
forms.' Only some 4,300 were eventually built before the company went bankrupt, and that after the government had already offered surety and actively manipulated the housing market to guarantee orders. ${ }^{104}$ Indeed, it is noteworthy that even after extra financial subsides were terminated by 1948 , government agencies actively continued to manipulate the public housing market to support non-traditional producers. ${ }^{105}$ Nevertheless, certain types were popular; or, at the very least, less unpopular. It was the larger, national companies that had fewer difficulties filling order books (again notably Wimpey and Laing, but to a lesser degree Wates), while the smaller, locally orientated producers like Reema and Spooner struggled to obtain a continuity of work, raising unit costs because of high central overheads. ${ }^{106}$ There were exceptions. The Cornish Unit, of which over 22,000 were built in the decade after 1945, proved popular in the south-west, partly because it was enthusiastically promoted by regional staff, partly because of the shortage of traditional builders in that area, but also because of its attractive, distinctive design: indeed Bevan wanted one as a country retreat. ${ }^{107}$

\section{CONCLUSION}

Customers (householders and local authorities) were noticeably less resistant to certain non-traditional designs after 1945 than they had been before 1939: meaning - how nontraditionals were understood and contextualised - had changed. Thus, there was a greater acceptance of certain house types that previously had been shunned.

Nevertheless, limits still existed as to what was more and was less acceptable, measured against the cultural 'gold standard' of traditional practice. This 'marked preference for the familiar in housing, for "quality", whether real or imagined', meant, according to one housing historian, that the foremost " "problem" [facing non-traditional diffusion] was social and political, for unless all sections of the community could agree on the desirability of mass-produced houses as consumer goods, there could be no success'. ${ }^{108}$ Two points spring from this. The first is an assumption that technological 'meaning' and 'direction' had also been satisfactorily resolved. The second revolves around the question of 'consensus', as outlined above or in terms of an 'end to controversy'. How should we measure it, how do we mark its attainment, is it a useful tool?

Clearly there are quantitative and qualitative problems with both points. With hindsight, we can judge that future trends in systems construction were to follow the paths favoured through late 1940s and early 1950s low-rise design. That is preference would be given to large prefabricated concrete panels and, at the other extreme, cast in situ concrete housing. The former was strongly advocated by scientific, technological and modernist architectural opinion, and was explicit in the 'ideal' promoted by politicians (the paymasters of public housing) — that modernising a 'backward' building industry involved the transfer of production from site to factory. In situ construction, by contrast, fell outside this rubric. Yet, ironically, it was here that customer resistance to changing consumption patterns was noticeably weaker. Indeed here we find positive acceptance - or certainly significantly less controversy amongst the relevant social groups. 'No fines' construction in practice meant building a 'traditional' house using non-traditional means, for the same or less money, more quickly, and with fewer problems in terms of labour and materials shortages. Off site prefabrication, however, had a different meaning. Initially, it represented standardisation and the manufacture of component parts for the industry as a whole. But in terms of popular exposure - which 
itself imparted important meaning — it signified whole house manufacture, and in terms of the implicit promises made: the mass production of houses. This, if you like, was the rehearsed 'dream' of publicists, manufacturers, modern architects. ${ }^{109}$

This new ideal was widely misunderstood, and indeed widely misrepresented. It is significant that even at times of acute housing shortages, customers at best subscribed to it only through a 'better than nothing' mentality. It was bitterly resisted, too, by the traditional industry - which rightly viewed it as a negative commentary on its own abilities - and by many architects. Was this unimportant? A consensus promoting prefabrication was unnecessary, it might be argued, because of the social authority of the groups supporting the proposition: those thought capable of legitimately speaking for the future (scientists, technologists, ideologues). Consensus, anyway, is an ideal construct: a widespread willingness to agree through common understanding across social groups is in fact unlikely. Perhaps then a better question to ask is to what degree, comparatively, was agreement reached - this being a less exacting requirement? Even here, however, there was no end to controversy, no social closure. The quality of conversation between consumer and producers remained, for the most part, marginal, and certainly not informing. So solutions were imposed, rather than agreed. No longer was successful innovation to be measured by an ability to mass-produce houses, but instead, the industrialisation of building simply meant that non-traditionals should be able to compete economically, using less skilled site labour. ${ }^{110}$ And, even against these more limited criteria, unanimity over prefabrication's achievements was lacking. This is not to say that a future course of direction had not been established. The largely unquestioned authority of science and technology, juxtaposed against continuing negative perceptions of traditional construction practice, continued to set the rules. That this failed to achieve an overarching hegemonic control in the ten years after 1945 because of consumer resistance does not mean that this did not occur later. But even then customers remained isolated, ignored, closure and stabilisation thwarted. The results were the inadequate, inappropriate solutions of the 1960s and 1970s.

${ }^{1}$ Public Records Office (hereafter PRO), HLG 36/18, Report of the Design of Dwellings Sub-Committee, 8 February 1944, para. 116.

${ }^{2}$ Raphael Samuels, Island Stories: Unravelling Britain. Theatres of Memory, Volume Two (London, 1998), 101-24.

${ }^{3}$ Christopher Powell, The British Building Industry Since 1800: An Economic History (London, 1996), 134.

${ }^{4}$ Nick Hayes, 'Making Homes by Machine: Images, Ideas and Myths in the Diffusion of Non-Traditional Housing in Britain 1942-54', Twentieth Century British History, 1999, 10: 295.

5 'Prefabrication: What will it mean in housing', Picture Post, 4 March 1944.

6 'Introduction: Strategic Research Sites', in Weibe Bijker, Thomas Hughes and Trevor Pinch (eds.), The Social Construction of Technological Systems; New Directions in the Sociology and History of Technology (Cambridge, Massachusetts, 1987), 191.

${ }^{7}$ Mass Observation, An Enquiry into People's Homes (London, 1943), 53, 156, 21 , Hayes, op. cit.(endnote 4), 297-8.

${ }^{8}$ Steven Fielding, Peter Thompson and Nick Tiratsoo, 'England Arise!' The Labour Party and Popular Politics in 1940s Britain (Manchester, 1995), 36-7. 
${ }^{9}$ Weibe E. Bijker, The Social Construction of Bakelite: Towards a Theory of Invention', in Bijker et al., op. cit, (endnote 6), 171-4.

${ }^{10}$ Steven Groák, The Idea of Building: Thought and Action in the Design and Production of Building (London, 1992), 38-9.

11 'Introduction', Biker, op. cit. (endnote 6), 12-13.

${ }^{12}$ Marian Bowley, The British Building Industry: Four Studies in Response and Resistance to Change (London, 1966), 325.

${ }^{13}$ Ibid.; Steven Groák and Graham Ive, 'Economics and Technological Change: Some Implications for the Study of the Building Industry', Habitat International, 1986, 10: 116-18, 125-8.

${ }^{14}$ David Mowery and Nathan Rosenberg, Technology and the Pursuit of Economic Growth (Cambridge, 1989), 9; Keith Pavitt, 'Sectoral patterns of technological change; Towards a taxonomy and a theory', Research Policy, 1984, 13: 365.

${ }^{15}$ W.J. McGhie, 'The Industrialisation of the Production of Building Elements and Components', Production of the Built Environment, 1983, 4: 32, 34-5; Groák, op. cit.

(endnote 10), 142; D. Sugden, 'The Place of Construction in the Economy', in D.A. Turin (ed.), Aspects of the Economics of Construction, (London, 1975), 16-17.

${ }^{16}$ Bengt-Åke Lundvall, 'Innovation as an interactive process: from user-producer interaction to the national system of innovation', in Giovanni Dosi, Christopher Freeman, Richard Nelson, Gerald Silverberg and Luc Soete (eds.), Technical Change and Economic Theory (London, 1988), 349-58.

${ }^{17}$ Pavitt, op. cit. (endnote 14), 356; McGhie, op. cit (endnote 15), 35.

${ }^{18}$ Nathan Rosenberg, Inside the black box: Technology and Economics (Cambridge, 1982), 66; Bowley, op. cit. (endnote 12), passim.

${ }^{19}$ PRO DSIR 4/592, I. Bowen, 'Productivity in the Building Industry'; C.M. Kohen, Works and Buildings (London, 1952), 448.

${ }^{20}$ Groák, op. cit. (endnote 10), ch. 3; Tavistock Institute, Interdependence and Uncertainty: A Study of the Building Industry (London, 1966), 39, 57.

${ }^{21}$ Bowley, op. cit. (endnote 12 ), 350.

${ }^{22}$ Ibid., 207-21.

${ }^{23}$ Patrick Dunleavy, The Politics of Mass Housing in Britain 1945-1975: A Study of Corporate Power, and Professional Influence in the Welfare State (Oxford, 1981); John Gold, The Experience of Modernism: Modern Architects and the Future City 1928-1953 (London, 1997), ch. 7; Fielding et al, op. cit. (endnote 8), 110-12; Junich Hasegawa, 'The Rise and Fall of Radical Reconstruction in 1940s Britain', Twentieth Century British History, 1999, 10: 137-61.

${ }^{24}$ Dunleavy, op. cit. (endnote 23), 3, 59-60, 342-52.

${ }^{25}$ Brian Finnimore, Houses From the Factory: Systems Building and the Welfare State (London, 1989), 240-1.

${ }^{26}$ Richard Nelson and Sidney Winter, 'In Search of Useful Innovation Theory', Research Policy, 1977, 6: 56-60; Giovanni Dosi, 'The Nature of the Innovation Process', in Dosi et al, op. cit., 222, 228.

${ }^{27}$ Finnimore, op. cit. (endnote 25); Dunleavy, op. cit.(endnote 23); Barry Russell, Building Systems, Industrialization, and Architecture (London, 1981); Robert 
McCutcheon, 'Modern Construction Technology in Low-Income Housing Policy', History of Technology, 1990, 12:136-76.

${ }^{28}$ Dunleavy, op. cit. (endnote 23), 177-8, 348-50; Finnimore, op. cit. (endnote 25), 18, 44-5, 238-45; Oonagh Gay, 'Prefabs: A Study in Policy-Making', Public Administration 1987, 65: 407-22; McCutcheon, op. cit. (endnote 27).

${ }^{29}$ Henkvan den Belt and Arip Rip, 'The Nelson-Winter-Dosi Model and Synthetic Dye Chemistry', in Bijker et al., op. cit. (endnote 6), 142.

${ }^{30}$ Giovanni Dosi and Luigi Orsenigo, 'Coordination and transformation: an overview of structures, behaviours and change in evolutionary environments', in Dosi et al, op cit. (endnote 16), 18.

${ }^{31}$ Finnimore, op. cit. (endnote 25), 18, 245; Hayes, op. cit. (endnote 4).

${ }^{32}$ Hayes, op. cit. (endnote 4); Robert McCutcheon, 'Major Participants in the UK Building Industry, 1964-1977', Habitat International 1988, 12:105-116.

${ }^{33}$ Hayes, op. cit. (endnote 4).

${ }^{34}$ Trevor Pinch and Wiebe Bijker, 'The Social Construction of Facts and Artifacts: Or How the Sociology of Science and the Sociology of Technology Might Benefit Each Other', in Bijker et al, op. cit. (endnote 6), 44.

${ }^{35}$ National Builder, March 1944. For the full report, see Ministry of Works, Methods of Building in the USA: The Report of a Mission appointed by the Minister of Works (London, 1944). In its conclusions it makes hardly a mention of prefabrication.

${ }^{36}$ J.B. Priestley, The English Journey (London, 1934, republished London, 1984), 300-3.

${ }^{37}$ David Jeremiah, Architecture and Design for the Family in Britain, 1900-70 (Manchester, 2000), 132; Brenda Vale, Prefabs: A History of the UK Temporary Housing Programme (London, 1995), ch. 3; Finnimore, op. cit .(endnote 25), 41-3.

38 'Fifty Thousand Brides Envy Her', Picture Post, 27 October 1945; 'A House Goes Up in a Day', Picture Post 21 September 1946; 'Prefabrication: What Will it Mean in Housing', Picture Post, 4 March 1944.

${ }^{39}$ Richard Sheppard, 'US Wartime Housing', Architectural Review, August 1944.

${ }^{40}$ Correlli Barnett, The Audit of War: The Illusion and Reality of Britain as a Great Nation (London, 1986).

${ }^{41}$ PRO HLG 94/7, Letter from McGuiness (Secretary of State for Scotland) to Burt Committee, 2 July 1943.

${ }^{42}$ Mass Observation, File Report 2270B, 'First Report on "The Post-War Home Exhibition”, 28 July 1945 (Harvester Microfiche, 1983).

${ }^{43}$ Ibid.

${ }^{44}$ Hayes, op. cit. (endnote 4), 291-3; David Dean, The Thirties: Recalling the English Architectural Scene (London, 1983), 9.

45 'RIBA on House Production', Architects' Journal, 19 April 1945; 'Prefabrication and the Builder', Architects' Journal, 6 December 1945.

46 'Prefabrication: A Policy', ibid., 20 December 1945.

${ }^{47}$ PRO HLG 94/1, Ledeboer, Burt Comm mins 27 March 1943.

${ }^{48}$ R. Fitzmaurice, 'Scientific Research on Alternative Methods of Construction for Permanent Houses: Part 1', Journal of the Royal Institute of British Architects (hereafter RIBA Journal), April 1947. 
${ }^{49}$ Post-War Building Studies (hereafter $P W B S$ ) No. 1, House Construction: by an Interdepartmental Committee Appointed by the Minister of Health, Secretary of State for Scotland and the Minister of Works (The Burt Committee), (London, 1944), 2-3. ${ }^{50}$ Architects' Journal, 6 April 1944. R. B. White, Prefabrication: A History of its Development in Great Britain (London, 1965), 154, makes a similar point.

${ }^{51}$ John Wilton, 'Prefabrication: Problems in the Development of a Technique', National Builder, July 1946.

${ }^{52}$ Mass Observation, loc. cit. (endnote 42), File 2270B; Mass Observation, File 2360, 'Modern Home Exhibition', 28 March 1946.

${ }^{53}$ Ibid.; Dex Harrison, 'An Outline of Prefabrication', in John Madge (ed.), Tomorrow's Houses: New Building Methods, Structures and Materials (London, 1946), 118; Richard Sheppard, 'Developments in Post-War Housing in 1944', Architects' Journal, 18 January 1944.

54 'Prefabrication: A Definition', Architects' Journal, 13 December 1945; Hugh Antony, Houses: Permanence and Prefabrication (London, 1945), 42.

${ }^{55}$ PWBS N $N^{o}$. 1, 1; 'Prefabrication and the Builder', Architects' Journal, 6 December 1945; 'Prefabrication II: A Policy', Architects' Journal, 20 December 1945.

${ }^{56}$ John Wilton, 'Prefabrication: The Need for Rational Development', National Builder, October 1946.

${ }^{57}$ Nick Hayes, 'Forcing Modernisation on the "one remaining really backward industry": British Construction and the Politics of Progress and Ambiguous Assessment', Journal of European Economic History 2002, 31: 321-50.

${ }^{58}$ For example, PRO CAB 124/553, Report by Advisory Council on Scientific Policy, 27 June 1947; CAB 124/553, Lord President's mins, 9 July 1948, 13 May 1949.

${ }^{59}$ PRO CAB 134/642, Bevan, 'House Building Costs', 16 June 1949; CAB 124/474, Morrison to Maud, 1 August 1945.

${ }^{60}$ H. Scott-Hume, 'Organisation for Production', National Builder, January 1945.

61 'Developments in Post-War Housing in 1944', Architects' Journal, 18 January 1945.

62 'Prefabrication', RIBA Journal, May 1944.

${ }^{63}$ Hayes, op. cit. (endnote 4); John Stevenson, 'Planners' Moon? The Second World War and the Planning Movement', in Harold Smith (ed.), War and Social Change: British Society in the Second World War (Manchester, 1986), 58-77.

${ }^{64}$ Fitzmaurice, op. cit (endnote 48); Richard Sheppard, Prefabrication in Building (London, 1946), 12, 15-17.

${ }^{65}$ Ministry of Health, Housing Returns for England and Wales 1946-55 (London).

${ }^{66}$ In 'no fines' concrete, sand was omitted, lightening and cheapening the mix, and thus lightening, too, the shuttering needed. This concrete mix also improved thermal insulation and prevented capillary attraction through the wall.

${ }^{67}$ Bowley, op. cit. (endnote 12), 213.

${ }^{68} P W B S N^{o}$ 1, 43-47, 53-56; PRO HLG 101/55, Procter to Taylor, 12 December 1944; HLG 94/5, 'First Interim-Report of the Inter-Departmental Committee', October 1943; HLG 94/7, Burt Comm. mins 17 June 1943, BC 46 'Experiments in House Construction'; HLG 94/6, Burt Comm. mins 15 April 1943, BC 36 'Report on Steel Framed Houses'.

${ }^{69}$ PRO CAB 134/642, mins 16 June 1949; CAB 87/36, mins 29 August 1945.

${ }^{70}$ Finnimore, op. cit. (endnote 25), 262. 
${ }^{71}$ PRO CAB 87/37, H (45) 13, 9 March 1945, note by Sandys.

${ }^{72}$ Finnimore, op. cit. (endnote 25), 268-71; White, op. cit. (endnote 50), 191-2; Housing Returns for Scotland 1946-55 (London); PWBS $N^{\circ}$ 25, House Construction: Third Report of Inter-Departmental Committee (London, 1948), 37.

${ }^{73}$ Bowley, op. cit. (endnote 12), 224; Mass Observation, File 2360, loc. cit. (endnote 42); Finnimore, op. cit. (endnote 25), 51-55; Nick Hayes, Consensus and Controversy: City Politics in Nottingham 1945-1966 (Liverpool, 1996), 42-3, 56, 81. The clear exception, in terms of appearance and popularity, were the temporary house types. For why this was so, see Vale, op. cit. (endnote 37), ch. 1.

${ }^{74}$ Bowley, op. cit. (endnote 12), 228, 231.

${ }^{75}$ PRO HLG 94/1, Building Research Station, Note No 844, February 1943.

${ }^{76}$ PRO HLG 94/4, Boxall to Symon 3 July 1943; HLG 94/7, Burt Comm. mins 10 August 1943, BRS, 'Memo on Experimental Building'.

${ }^{77}$ Ministry of Works, Advisory Council on Building and Research and Development: First Report (London, 1949), 12.

${ }^{78}$ Fitzmaurice, op. cit. (endnote 48).

${ }^{79}$ PRO HLG 94/8, Burt Comm. mins 13 July 1944 \& 17 August 1944.

${ }^{80}$ Ibid., 29 November 1945 \& 17 January 1946. See Russell, op. cit. (endnote 27), 65168 , for subsequent problems generally.

${ }^{81}$ PRO HLG 101/635, 'Expansion of Non-Traditional Programme', 13 May 1952.

${ }^{82}$ PRO HLG 36/21, CHAC PW 64, 'The Appearance of Housing Estates', 1947; Mass

Observation, File 2360, loc. cit..

${ }^{83}$ PRO HLG 102/371, Smith to Hickinbotham, 7 January 1952.

${ }^{84}$ PRO CAB 134/642, 'House Building Costs, 16 June 1949.

${ }^{85}$ R. Fitzmaurice, 'Changes in Building Technique', National Builder, December 1949. ${ }^{86}$ Ibid.

${ }^{87}$ See, for example, National Federation of Building Employers Annual Report 1943, 10; National Builder, March 1945.

${ }^{88}$ Hayes, op. cit. (endnote 4), 303; J.D. Bernal, 'Building Research', National Builder, March 1946.

${ }^{89}$ Ministry of Works, National Building Studies Special Report $N^{o} 4$ : New Methods of House Construction (London, 1948), 4; PRO HLG 101/371, Hickinbotham to Wilkinson, 4 February 1952; HLG 101/371, Policy Comm. on Non-Traditionals, c. Jan 1952.

${ }^{90}$ Ministry of Works, National Building Studies Special Report $N^{\circ}$ 10: New Methods of House Construction Second Report (London, 1949); Bowley, op. cit. (endnote 12), 243-8, Hayes, op. cit. (endnote 4), 304-7.

${ }^{91}$ R. Fitzmaurice, 'Scientific Research on Alternative Methods of Construction for Permanent Houses Part 2', RIBA Journal, May 1947.

${ }^{92}$ Finnimore, op. cit. (endnote 25), 169-83, 197-201; Dunleavy, op. cit. (endnote 23), 848; Graham Towers, Shelter is Not Enough: Transforming multi-storey housing (Bristol, 2000), 52-62; Powell, op. cit. (endnote 3), 187-9.

${ }^{93}$ PWBS N $1,139$.

${ }^{94}$ J. Bronowski, 'Operational and Statistical Research in Building', Architects' Journal, 29 March 1951; NBS No4, op. cit. (endnote 89), 3, passim. 
95 Anglo-American Council on Productivity, Building: Report on a visit to the USA in 1949 of a Productivity Team representing the Building Industry (London, 1950), 40; Ministry of Works, Working Party Report Building (London, 1950), 39; Ministry of Health, The Cost of House Building: First Report of the Committee of Inquiry (London, 1948), 49-50.

${ }^{96}$ PRO CAB 124/553, Tomlinson to Morrison, 7 January 1946; Morrison to Key, June 1947.

${ }^{97}$ Fitzmaurice, 'Influence of Mechanisation and Prefabrication on Techniques and Cost of Building', National Builder, October 1951; Durbin, Operative Builder, September 1948.

${ }^{98}$ Dunleavy, op. cit. (endnote 23), 110-114; Hayes, op. cit. (endnote 4), 288-91;

McCutcheon, op. cit., (endnote 32), 113.

${ }^{99}$ Bowley, op. cit. (endnote 12), 228-31.

${ }^{100}$ Finnimore, op. cit. (endnote 25), 44.

${ }^{101}$ Sheppard, op. cit., (endnote 64), 48; James Strike, Construction into Design: The Influence of New Methods of Construction on Architectural Design 1690-1990 (Oxford, 1991), 123.

${ }^{102}$ Sheppard, op. cit. (endnote 64), 56, 59; PRO HLG101/56, mins 13 February 1946; Architects' Journal, 5 October 1944.

${ }^{103}$ White, op. cit. (endnote 50), 151-4, 160, 300; Strike, op. cit. (endnote 101), 154.

${ }^{104}$ PRO HLG 101/56, Bevan, note c. Oct 1945; Scott to Symon, 19 October 1945; PWBS $N^{o} 25,29-33$.

105 Finnimore, op. cit.(endnote 25), 63-6; Hayes, op. cit., (endnote 4), 304-7.

${ }^{106}$ PRO HLG 101/635, Expansion of the Non-Traditional Programme', 13 May 1952; Hickinbotham to Wilkinson, 21 May 1952.

${ }^{107}$ Hayes, op. cit. (endnote 4); Michael Foot, Aneurin Bevan 1945-1960 (London, 1973), 81.

${ }^{108}$ White, op. cit. (endnote 50), 127-8.

${ }^{109}$ For example, Le Corbusier, Towards a New Architecture (Paris, 1923, reprinted Woburn, 1970 edn.), 229-65; Walter Gropius, Bauhausbücher, Vol. 3: Ein Versuchshaus des Bauhauses (Munich, 1924), reprinted in Gropius, Scope of Total Architecture (London, 1956), 143-54; Sheppard, op. cit. (endnote 64); Antony, op. cit. (endnote 54).

${ }^{110}$ McCutcheon, op. cit. (endnote 27). 